University of Louisville

ThinkIR: The University of Louisville's Institutional Repository

Electronic Theses and Dissertations

1947

\title{
The nature of the amenorrhea of lactation in humans.
}

Carroll H. Luhr

University of Louisville

Follow this and additional works at: https://ir.library.louisville.edu/etd

Part of the Physiology Commons

\section{Recommended Citation}

Luhr, Carroll H., "The nature of the amenorrhea of lactation in humans." (1947). Electronic Theses and Dissertations. Paper 2053.

https://doi.org/10.18297/etd/2053

This Master's Thesis is brought to you for free and open access by ThinkIR: The University of Louisville's Institutional Repository. It has been accepted for inclusion in Electronic Theses and Dissertations by an authorized administrator of ThinkIR: The University of Louisville's Institutional Repository. This title appears here courtesy of the author, who has retained all other copyrights. For more information, please contact thinkir@louisville.edu. 
THE NATURE of the AMENORRHEA

of

LACTATION In HUMANS

Carroll H. Luhr, Jr., M.D. 


\title{
UNIVERSITY OF LOUISVILLE
}

THE NATURE of the AMENORRHEA Of LACTATION In HUMANS

\author{
A Dissertation \\ Submitted to the Faculty of the \\ Graduate School of the University of Louisville \\ in Partial Fulfillment of the \\ Requirements for the Degree \\ of Master of Science
}

Department of Pathology

Carroll H. Luhr, Jr., M.D.

1947 


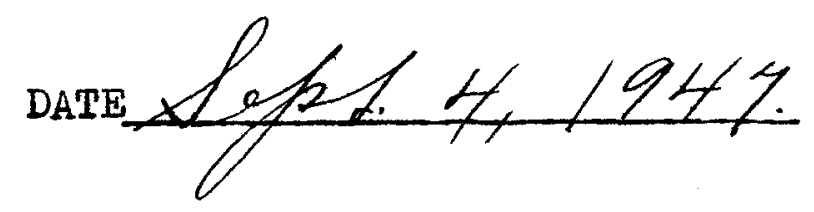

APPROVED BY

COMMITTEE:

$\frac{\text { A. James Miller }}{\text { L. A. Gray }}$




\section{ACKNOWLEDGEMENT}

I am glad to have this opportunity to thank Dr. A.J. Miller and Dr. L.A. Gray, in whose departments this work was done, for their assistance, recommendations, and stimulating interest. I take pride in having been associated with teachers of their high caliber and I am grateful for all that I have learned from them.

I would like to acknowledge Dr. John Walker Moore's friendly encouragement and recommendations for me to undertake graduate medical work.

I appreciate the technical assistance given by Miss Gertrude Limper who prepared the sections of endometrial biopsies. 


\section{CONTENTS}

\section{INTRODUCTION}

II REVIEW Of IITERATURE ON ILACTATION AMENORRHEA

III PURPOSE

IV EXPERIMENTAL PROCEDURE

$V$ TABLE of DATA

VI DISCUSSION of FINDINGS

VII CONCLUSIONS

VIII SUMMARI

IX BIBLIOGRAPHY 


\section{INTRODUCTION}

The Idea, popular among the laity, that the amenorrhea associated with the period of lactation gave protection against conception is, of course, known to the medical profession to be unfounded. It is obvious to those interested, however, that not all women fail to menstruate during lactation and that pregnancy does occur in a reasonable number of instances either before menses resume or after the cycle has re-established. Likewise, the reappearance of menses does not seem to decrease or influence the secretion of breast milk, therefore, the endocrine systems responsible for lactation and menstruation may not necessarily be reciprocally related.

An observation made some years ago and reported in 1943 by Fortune indicates that Arapesh women do not resume menses during lactation before the infant has cut its first incisors, although Caucasian women may menstruate earlier. These women are an inbred group (8000 or less) with a characteristic long lactogenic interval. Nursing for three years, which is common among these women, does not produce amenorrhea for that length of time. (1).

With these simple and gross observations in mind it was decided to study the problem of the Nature of the Amenorrhea of Lactation in Humans. 


\section{REVIEW OF LITERATURE}

A careful review showed thearticles written on this subject to be sparsely distributed throughout the literature. Everyone agreed about the growth and development of the breast and the process by which lactation occurs, but the effect of lactation on the menstrual cycle has not been well described.

Novak and Hoskins agree on the theory that at puberty the ovarian hormones, estrogen and progesterone, will stimulate the anterior pituitary to increase the secretion of a duct growth factor (mammogenic hormone). During pregnancy progesterone plus estrogen (placental hormones) causes an increased secretion of lobule-alveolar growth factor and is responsible for proliferation of alveolar ducts and lobules. Theories about why lactation does not occur during pregnancy are, 1. that the placenta produces a lictation suppressing agent, 2. that the distended uterus inhibits lactation, 3. that the secretion of progesterone by the corpus luteum during pregnancy inhibits lactation, 4. that the lactogenic hormone is inadequate during pregnancy and is increased 2-4 times within a short time after parturition. Novak's only comment about menstruation and ovulation during lactation was to reiterate that ovulation is followed by menstruation if fertilization does not take place, therefore, menstruation without ovulation is possible but ovulation without menstruation is impossible unless pregnancy intervenes.

Hoskins (2) assumes that menstrual failure during lactation is due to the action of a mammary hormone exerted either 
directly on the ovaries or via the anterior-pituitary to cause a persistence of corpus luteum which in turn arrests the cyclic process. It is more probable that the prolactin Hormone is responsible for this.

One of the most informative papers published was one by Paul Topkins (3) in 1943. His purpose was to determine the extent of ovarian inhibition during lactation. For his study he chose to examine the endometrium by biopsy during the period of lactation. He assunes that if progestational (progesteronal) endometrium is formed, then ovulation has taken place and that the absence of such an endometrium indicates, but does not prove, an absence of ovulation, (4). He further states that fillure of ovilation cannot definitely be established without microscopic study of the ovaries unless you assume ovulation is always followed by luteinization and that Iuteinization always produces a secretory endometrium. Sinee the endometrium usually regenerates in three weeks post-partum, except at the placental site, where about seven weeks is required, Topkins began his biopsies at the 6th postpartum week. He took 145 specimens from 28-women, eight colored and twenty white, who had had previous regular periods before pregnancy and who were otherwise gnnecologically normal. Four biopsies were taken from each patient and classified as estrogenic and progestational and the number of weeks post-partum noted. One hundred thirty six (136) op $94 \%$ proved to be estrogenic - and of that $94 \%$ - $15 \%$ were poorly developed or hy po- 
estrogenic whereas $85 \%$ were fairly well developed and constant throughout the amenorrhea, showing mid-follicular phase (end of Ist week of cycle) endometrium. The remaining $6 \%$ showed progestational endometrium and all were associated with the onset of the first menstrual flow.

Topkins concluded that (1) the endometrium in lactation amenorrhea shows diminished estrogen stimulation, (2) during lactation the ovarlan cycle is suppressed completely in amenorrhea and incompletely in lactation menstruation, (3) on the basis of animal experimentation, inhibition of ovarian activity is the result of suppression of gonad atrophic activity of the hypophysis and that (4) suppression of gonadatrophic activity, in turn, is due to the action of prolactin or else to a hormone of the lactating mammary gland not yet isolated.

He suggests that $85 \%$ of cases of unäifferentiated endometrium, as in the first week of the cycle, indicates that the follicle is not fully developed and that $15 \%$ of cases with hy poplasia suggest that those follicles are regressing. This study indicates that in lactation amenorrhea there is inhibition of ovarian activity, the follicies failing to mature to the point of rupture. Topkins also further concludes that it is reasonable to assume if luteinizing hormone is responsible for lactation amenorrhea then ovulation would be present, which it is not.

We now know, however, that pure Follicle stimulating Hormone will stimulate the ovarian follicle to the point of morphological development but does not cause the secretion of estrogen. 
The addition of Luteinizing Hormone (L.H.) is necessary to produce estrogen and for rupture of follicles to occur, (5). Another careful study is reported by Cherry (6), who in 1986-37 described the action of the mammary gland on the ovary. His paper states that the mammary gland develops under the influence of estrogen and when primed by the corpus luteum hormone the administration of estrogen will stimulate lobularalveolar development. During pregnancy estrogen is present in large amounts in the circulation, reaching a peak shortly before parturition and falling markediy after parturition. This fall in estrogen releases the inhibitory action on the pituitary gland and prolactin or lactogenic hormone is released under the sucking reflex stimulus, which is a function of the hypothalmus. Cherry then explains the lack of menstruation in a majority of women during lactation on the basis that there is a low estrogen level in the circulation that is inhibited by some antagonistic hormone action from the lactating breast, preventing the maturation of the ovarian follicle. This action, he thinks, varies in intensity and it is assumed that when ovulation, menstruation or pregnancy do occur during lactation that the pituitary has overcome this inhibition. Cherry, too, assumes the ovarian failure is probably secondary to pituitary suppression. Cherry's investigation was based on a theory that the breast produced a substance at the beginning of lactation which inhibited maturation of the ovarian follicle and ovulation. He injected alcohol precipitates of pregnancy urine and extracts of lactating mammary 
gland into albino rats. In the gonadatrophic injected controls corpora hemorrhagica and corpora lutea developed in every instance. In the controls injected with extracts of mamary gland no change was noted either macroscopically or microscopicaliy. When the two extracts were mixed in the same syringe and given together the result in most instances was complete absence of corpora hemorrhagica and corpora lutea. Follicular development was present in the majority of instances, but in some animals this too was absent, as confirmed by negative vaginal smears and microscopic sections.

Further work on the rabbit proved there was a definite inhibitory action of the lactating mammary gland on the ovary. Griffith and McBride (7) in 1939 reported 21-post partum patients exanined and biopsied at intervals varying from three to twenty-four weeks. Ten patients nursed their babies from two to nine months and eight of these, $80 \%$, began to have menstrual periods and ovulation only after weaning. The average duration of nursing was $3 \frac{3}{2}$-months, followed by anovulatory flow at five months and by the first ovriation at 5 -months. Two patients, 20\%, had regular menses (ovulatory) during their period of lactation. One of these had menstrual perlods beginning after two months, ovulation after five months. She nursed her child seven months. Another had menstrual periods röestablished after six months, ovulation after 6 -months. She weaned her child at age nine months.

Eleven patients unable to nurse babies had menstrual periods beginning on an average of two months post-partum and ovulation at five months post-partum or later. 
In $95 \%$ of these cases an anovulatory flow preceded ovulation. These authors assume, as does Topkins, that Pituitary Gonadatrophin is immediately suppressed, probably due to the lactogenic hormone or some other unknown internal secretion.

Further studies along the same theme done by Kurzrok, Lass and Smelser (8) consisted of biopsies done on thirty women who were simultaneously lactating and having regular menstrual cycles. They establish in their series tinat $65 \%$ of these cycles are sterile or anovulatory periods. A year later(9), in 1938, these same authors presented another study relating to the time of human ovulation during lactation, in which they again biopsied postpartum women who were nursing regularly and having regular catamenia. The presence of secretory endometrium indicates ovulation and the presence of non-secretory endometrium within ten days of the succeeding menstrual flow indicates an enovulatory cycle in their series. Forty-seven women were studied by biopsy at four week intervals and $55 \%$ of these cycies were anovulatory and $45 \%$ were ovrulatory.

Pregnandiol output in the urine is now accepted as an index of corpus luteum activity in both the pregnant and non-pregnant woman. Fifty-one cases of pregnandiol excretion were studied during the first post-partum week by Wilson, Randall and Osterbery showing evidence that some pregnandiol is present immediately after parturition but in amounts less than those found antepartum (10). Estimates of pregnandiol on the 4th post-partum day showed $45 \%$ negative, $21 \%$ minimal and $34 \%$ with a mean value of 2.75 to 6-mgms per 24-hours. This may indicate some corpus 
Iuteum function post-partum and its association with lactation is not yet known.

Robinson (11) discusses the subject from the opposite point of view, namely: if menstrual periods are resumed or if pregnancy does occur during lactation does milk secretion stop? He interviewed over 600 mothers regarding the age of weaning and the time their menstrual periods resumed. He concluded that menstruation is neither a reason for weaning nor a cause for failure of lactation; these functions seem to be independent of lactation. In the series of women pregnant and simultaneously lactating, many pregnancies went unnoticed until foetal movements were felt. By this time the foetus is 18-20 weeks old and the nursing infant seven months old which means that adequate lactation had continued for five months of pregnancy. By seven months lactation normally diminishes so the lowered output after that could not be attributed to the pregnancy.

other work based on animal experimentation has been published and where possible has been applied in theory to humans. Bates, Iahr and Riddle (12) in 1935 showed that data concerning the action of F.S.H. and prolactin on the ovary and sex accessories of fowls fell into two contrasting groups demonstrating directly opposite effects. Prolactin stopped ova production and caused decrease in ovarian weight. F.S.H. stimulated ova production, stopped laying and increased ovarian weight markedly. Prolactin decreased oviductal and uterine size, comb size and pubic bone wiath, whereas F.S.H. increased the size of these structures. 
Lahr and Riddle (12) injected Prolactin into non-lactating rats and observed suspension of two to four estrous cycles with large undegenerated corpora lutea in the ovaries. Progesterone produced no such effect. Riddle and Bates (13) in 1933 showed prolactin to cause regression in the weight of the testis of a pigeon and concluded the same to be true of the ovary. They therefore offer the possibility that the gonadstimulating (sex-maturing) hormone is hela in abeyance by circulating prolactin. Turner and Meitus (14-15) showed that in rabbits the lactogenic hormone which was low during pregnancy increased $2-4$ times after parturition and this increase was not influenced by a simultaneous pregnancy. Finally in 1934 Collip, Selye and Thomson (16) presented the idea that the stimulus of sucking was also involved in this problem via the hypothalmus. They believe suckling stimulates the anteriorpituitary to produce prolactin and to modify its activity toward the ovary so that corpora lutea of post-partum ovulation long retain their healthy structure and active function while further ovulation and phenomena of estrus are inhibited.

From these articles it is evident that much is still to be learned about the physiological actions of these endocrine glands during lactation.

Further light was shed on the subject by Albright, Smith and Dodge (17) when in their presentation of a new method of assay of pituitary F.S.H. they review a case of secondary amenorrhea with persistent lactation after 2 -years. The F.S.H. output per-24-hours in this patient fell. within the normal 
limits instead of being suppressed and they promised a further investigation of the problem of lactation amenorrhea.

\section{PURPOSE}

The idea that the F.S.H. output per 24-hours may consistently be within normal limits is the basis for the following investigation. The hormone level will be determined by urinary assay and correlated with the simultaneous endometrial biopsy findings in an attempt to not only confirm other work done on the incidence of ovilation during lactation but also to determine the true status of the pituitary activity.

\section{EXPERIMENTAL PROCEDURE}

Thirteen colored females were selected from the PostPartum Clinic at the Louisville General Hospital at the time of their regular six weeks post-partum examination. These women were biopsied and an assay of urinary F.S.H. was taken simultaneously. All of the patients were in good general health and had had no previous menstrual irregularities. These women were examined at various intervals between their 6 th and 19th post-partum week. The incidence of non-secretory and secretory endometrium was observed; the level of Pituitary F.S.H. output per 24-hours was determined and the presence or absence of menstruation was noted during their period of lactation . The data is compiled in charts and is here discussed. One case 
of persistent amenorrhea in a patient 14-months post-partum is presented.

Discussion regarding the method of hormone assay is needed. The procedure used is that described and confirmed by Smith, Albright and Doâge, (17-18), in 1943. An eight hour overnight urine specimen is filtered and if necessary acidified with acetic glacial/acid. One gram of sodium chloride per $100 \mathrm{cc}$ of urine is added and four volumes of $95 \%$ ethy 1 alcohol. This is cooled overnight in the refrigerator and the precipitate collected in a 250 cc centrifuge bottle. The precipitate is washed with anhydrous ether and dried overnight in a vacuum dessicator. The precipitate is then redissolved in water, $30-45 \mathrm{cc}$, and dialysized for four hours against running tap water to remove impurities and render the specimen less toxic. The product of dialysis is re-precipitated by adding .I $\mathrm{gm} \mathrm{NaCl}$ to the whole specimen $(45-c c)$ and four volumes of ethy $I$ alcohol. This is cooled overnight and the precipitate collected in a 50 cc centrifuge tube and again dried with anhydrcus ether overnight in a dessicator. This precipitate is stable at room temperature and when ready for use is dissolved in $5.5 \mathrm{cc}$ of distilled water and kept refrigerated until the assay is completed. White mice 19 to 20 days olỏ and weighing 7-10 gms are used for the assay and are injected subcutaneously in the back with $2 \frac{1}{z-c c}$ of test solution over a period of three days, recelving $c c$ at each injection. Twanty-four hours after the last injection the mouse is autopsied and the uterine weight determined by removing it, pressing it between filter paper to remove the excess tissue fluid and weighing it on a balance. 
One mouse unit of hormone is the amount required to produce 100-150\% increase in the size of the uterus (weight). Nornally the uterus in animals injected with saline as controls weighed $3.7 \mathrm{mgs}$ f or $-.9 \mathrm{mgms}$ as reported by Albright, et al. In this series, and with this particular strain of mice, 14 animals kept as controls had an average uterine weight of $3.28 \mathrm{mgm}$. The final precipitate contains all the hormone excreted by that patient in an eight hour period, therefore if $2.5 \mathrm{cc}$ of this $5.5 \mathrm{cc}$ solution contains one or more Mouse Units (Mu) as indicated by a positive test, then the 5.5 ce will contain $2.2 \mathrm{Mu}$. The patient's output for 24-hours would then be 6.6 Mu. By making appropriate dilutions with water the original specimen may be further assayed for higher levels of F.S.H. The level for normal regularly menstruating women, not pregnant and not lactating, is more than 6.6 and less than $53 \mathrm{Mu}$ units in 24-hours, according to standards reported by Albright, Smith and Dodge. These authors stress the importance of the F.S.H. test, in that at present it is the only anterior pituitary hormone that can be assayed easily and also suggest that 1 t be applied further clinically. The procedure is simple in technique, its main fault being the amount of time required to prepare one specimen for assay (44-92 hours) - (5).

Regarding the use of the alcohol precipitate test, Heller and Heller (19) cite five advantages of this method over other extractions, chiefly the tannic acid or tungstic acid precipitates. It is simple and direct, the products are stable for storage at any stage, the F.S.H. is concentrated many times, 
dialysis removes a large percentage of the toxicity (probably by removal of salts), potency is not affected by detoxification, just as large or larger amounts of hormone are recovered with this method. The use of the mouse uterus as the endpoint for the assay was established by Levin and Tyndale (20). This proved to be a more accurate and more sensitive test than did follicular enlargement, increase in ovarian weight or vaginal canalization. These authors established the absence of estrogenic substances in the urine by injections into spayed rats as well as by the fact that all potency was destroyed by heating, acid treatment and other procedures which would not injure estrin, had it been present. The uterine response was $67 \%$ greater if mice were autopsied 72-hours after the first in jection.

The endometrial biopsies were made with a Novak curette, after cleansing the cervix with Merthiolate. The tissue obtained was fixed with Formalin (10\%), sectioned and stained with $\mathrm{H} \& \mathrm{E}$. as a routine procedure of this clinic. Classification as to secretory or non-secretury activity is made on the basis of the standard text books of cynecology (Novak). 


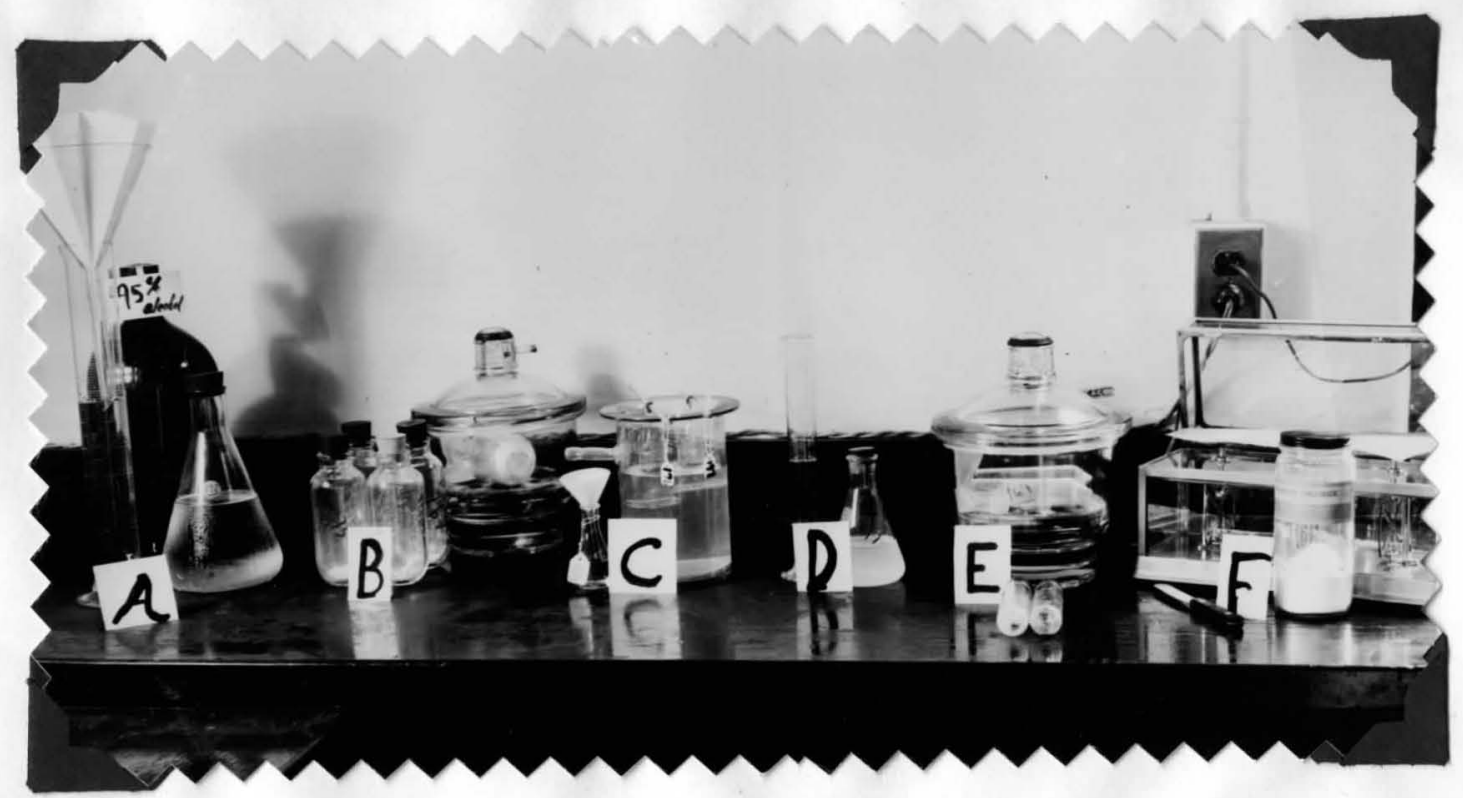

A. Acidified Filtered Urine with Alcohol Added.

B. First Precipitate.

C. Dialysis Process.

D. Dialysized Specimen with Alcohol Added.

E. Second Precipitate.

F. NaCl \& Balance.

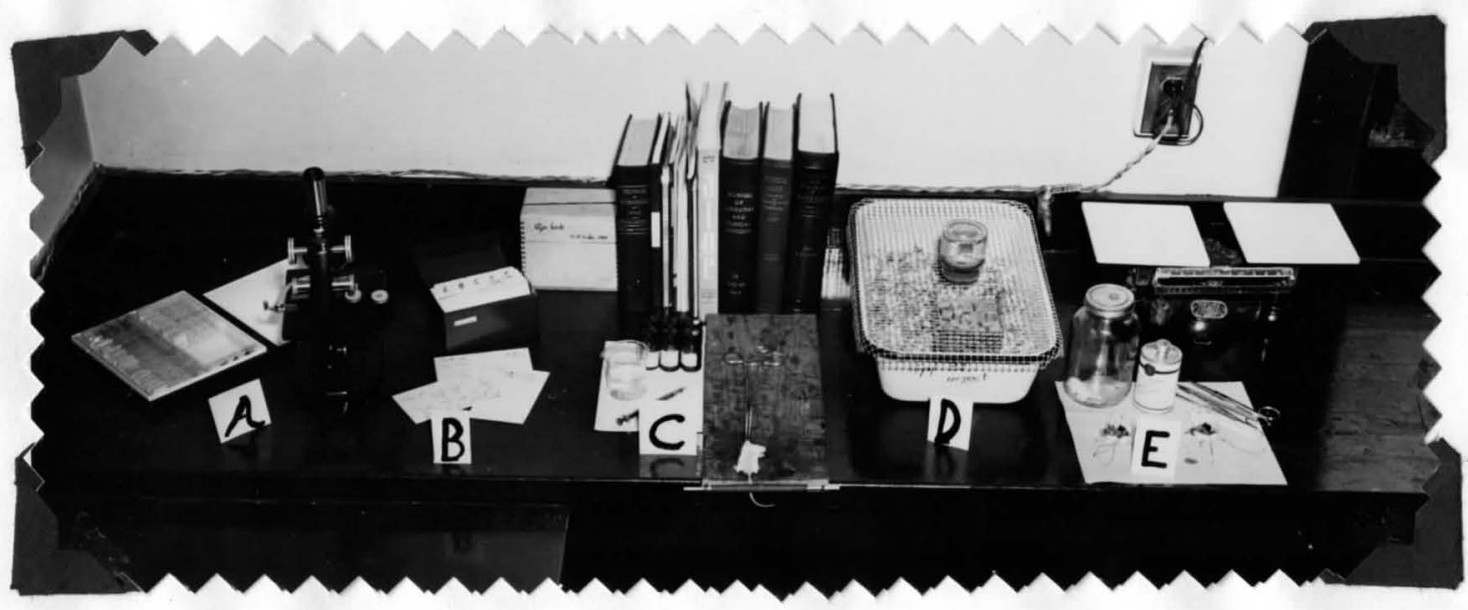

A. Biopsies - sections.

B. Index File.

C. Mouse board - lco syringe - Specimen Bottles.

D. Usual ty pe breeding pan.

E. Autopsied mice. 


\section{IACTATION AMENORRHEA DATA}

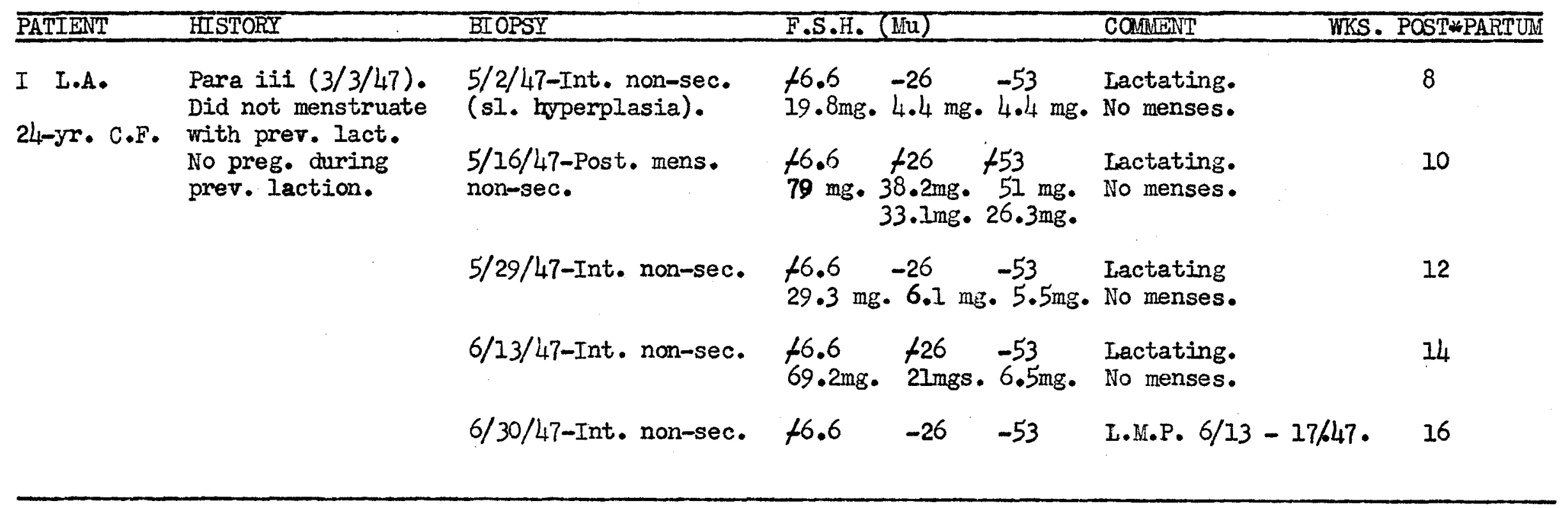

2. M.E.B. Para iii (3/2/47). 4/11/47-Int. Non-sec. 66.6 t26 -53 Bleeding 3-days beg. 6 I.M.P. 3-days bez. (sl. hyperplasia). 32.Img. 15.2mg. 5.2mg. $4 / 11 / 47$.

$24-\mathrm{yr}$. C.F. $4 / 11 / 47$. No cramp. Did not mens. during 4/25/47-Int. non-sec. $46.6 \quad+26 \quad-53 \quad$ Iactating. lactation. $66 \mathrm{mg}$. $19.1 \mathrm{mg} .5 .1 \mathrm{mg}$.

\begin{tabular}{|c|c|c|c|c|}
\hline $\begin{array}{l}\text { 5/16/47-Post-mens. } \\
\text { non-sec. }\end{array}$ & $\begin{array}{l}46.6 \\
10.7 \mathrm{mg} .\end{array}$ & $\begin{array}{l}-26 \\
3 m g .\end{array}$ & -53 & $\begin{array}{l}\text { Scant bleeding } 1 \\
\text { days beg. } 5 / 11 / 47 \\
\text { Lactating. }\end{array}$ \\
\hline 6/20/47-Int.non-sec. & $\begin{array}{l}46.6 \\
12.8 \mathrm{mg} .\end{array}$ & $\begin{array}{l}-26 \\
5 m g .\end{array}$ & & $\begin{array}{l}\text { I.I.P. } 6 / 17 / 47 . \\
\text { Scant one day. } \\
\text { Lactating. }\end{array}$ \\
\hline
\end{tabular}




\begin{tabular}{|c|c|c|c|c|c|c|}
\hline PATIENT & HISTORY & BIOPSY & F.S.H.(Mu) & & COMAENT & WKS.POSTWPARTUM \\
\hline \multirow{4}{*}{$\begin{array}{l}\text { 3. I.B. } \\
27-\text { gr. C.F. }\end{array}$} & \multirow{4}{*}{$\begin{array}{l}\text { Para i }(2 / 20 / 47) \\
\text { Lactating. } \\
\text { No menses. }\end{array}$} & $\begin{array}{l}\text { 4/4/47-Int. non.sec. } \\
\text { S1. hyperplasia. }\end{array}$ & $\begin{array}{l}46.6 \\
8.4 \mathrm{mg} .\end{array}$ & $\frac{-53}{3.5 \mathrm{mg} .}$ & Lactating. & 6 \\
\hline & & $\begin{array}{l}\text { 4/18/47-Int.nonsec. } \\
\text { (Thrombosis) }\end{array}$ & $\begin{array}{ll}-5.6 & -6.6 \\
6.4 \mathrm{mg} \cdot & 3.5 \mathrm{mg} .\end{array}$ & s. & Lactating. & 8 \\
\hline & & 5/2/47-Int.non-sec. & $-^{-26} .5 \mathrm{mg}$ & $\begin{array}{l}-53 \\
4.3 \mathrm{mg}\end{array}$ & $\begin{array}{l}\text { Lactating. } \\
\text { No menses. }\end{array}$ & 10 \\
\hline & & 5/16/47-Int. non-sec. & $\begin{array}{l}+6.6 \\
49.3 \mathrm{mg} . \\
-3.3 \mathrm{mg} .\end{array}$ & $\begin{array}{l}-53 \\
3.3 \mathrm{mg}\end{array}$ & $\begin{array}{l}\text { Lactating. } \\
\text { No menses. }\end{array}$ & 12 \\
\hline \multirow{4}{*}{$\begin{array}{l}\text { 4. E.B. } \\
\text { 29-yr. C.E. }\end{array}$} & \multirow{4}{*}{$\begin{array}{l}\text { Para vi }(2 / 6 / 47) \text {. } \\
\text { Lact. No menses. } \\
\text { Did mens. during } \\
\text { prev. lact. Did } \\
\text { become pregnant } \\
\text { during a previous } \\
\text { lactation. }\end{array}$} & 4/II/47-Int. non-sec. & $\begin{array}{ll}t 6.6 \quad+26 \\
40.8 \mathrm{mg} . & 12.2 \mathrm{mg} .\end{array}$ & $\begin{array}{l}-53 \\
-5.1 \mathrm{mg} .\end{array}$ & Lactating. & 9 \\
\hline & & 4/25/47-Int. non-sec. & $\begin{array}{ll}46.6 & -26 \\
24.1 \mathrm{mg} . & 5.2 \mathrm{mg} . \\
4.3 \mathrm{mg} .\end{array}$ & $\begin{array}{l}-53 \\
4.8 \mathrm{mg} .\end{array}$ & $\begin{array}{l}\text { Lactating. } \\
\text { No menses. }\end{array}$ & 11 \\
\hline & & 5/9/47-Int. non-sec. & $\begin{array}{ll}-6.6 & -6.6 \\
5.1 \mathrm{mg} . & 3.0 \mathrm{mg} .\end{array}$ & & $\begin{array}{l}\text { Lactating. } \\
\text { No menses. }\end{array}$ & 13 \\
\hline & & 5/23/47-Int. non-sec. & $\begin{array}{ll}-6.6 & -26 \\
9.2 \mathrm{mg} . & 3.0 \mathrm{mg} .\end{array}$ & $\begin{array}{l}-53 \\
3.2 \mathrm{mg} .\end{array}$ & $\begin{array}{l}\text { Lactating. } \\
\text { No menses. }\end{array}$ & 15 \\
\hline \multirow{2}{*}{$\begin{array}{l}\text { 5. R.C. } \\
\text { 16-yr. C.F. }\end{array}$} & \multirow{2}{*}{$\begin{array}{l}\text { Para i }(2 / 16 / 47) \\
\text { Lactating. } \\
\text { No menses. }\end{array}$} & 4/4/47-Int. non-sec. & $\begin{array}{ll}+6.6 & +26 \\
30.6 \text { mg. } & 20 \text { mis. }\end{array}$ & $\begin{array}{l}-53 \\
5.6 \mathrm{mg} .\end{array}$ & & 7 \\
\hline & & 4/18/47-Int. non-sec. & $\begin{array}{ll}+6.6 & +26 \\
57.2 \mathrm{mg} . & 10.2 \mathrm{mg}\end{array}$ & $\begin{array}{l}-53 \\
\text { gg. } 3.9 \mathrm{mg} \text {. }\end{array}$ & $\begin{array}{l}\text { Lactating. } \\
\text { No menses. }\end{array}$ & 9 \\
\hline$\%, 0 \% \%$ & & & & & & \\
\hline
\end{tabular}




\begin{tabular}{|c|c|c|c|c|c|}
\hline PATIENT & BISTORY & BIOPSY & F.S.H.(Mu) & COMMENT & WKS.POST-PARTUM \\
\hline \multirow[t]{4}{*}{$\begin{array}{l}\text { 6. I.B. } \\
\text { 2I-Jr. C.F. }\end{array}$} & \multirow{4}{*}{$\begin{array}{l}\text { Para ii }(1 / 25 / 47) \\
\text { Lactating. No mens. } \\
\text { No mens. during } \\
\text { prev. lactation. }\end{array}$} & $\begin{array}{l}\text { 4/25/47-Int. non-sec. } \\
\text { old decidual reaction. }\end{array}$ & $\begin{array}{l}46.6 \quad+26 \quad-53 \\
27.7 \mathrm{mg} \cdot 10.5 \mathrm{mg} \cdot 4 \cdot 6 \mathrm{mg} \cdot\end{array}$ & $\begin{array}{l}\text { Nursed lst baby } \\
\text { 9-mos. Mens. } \\
\text { 13-mos. }\end{array}$ & 13 \\
\hline & & 5/9/47-Int. non-sec. & $\begin{array}{lccc}f 6.6 & +26 & -26 & -53 \\
33 \mathrm{mg} \cdot & 12 \mathrm{mg} \cdot 3 \mathrm{mg} \cdot 3 \mathrm{mg} \cdot 3 \mathrm{mg}\end{array}$ & $\begin{array}{l}\text { Lactating. } \\
\text {.No mens. }\end{array}$ & 15 \\
\hline & & 5/23/47-Int. non-sec. & $\begin{array}{ll}46.6 & 426 \\
28.4 \mathrm{mg} \cdot & -53 \\
20.6 \mathrm{mg} \cdot & 4.1 \mathrm{mg} .\end{array}$ & $\begin{array}{l}\text { Lactating. } \\
\text { No menses. }\end{array}$ & 17 \\
\hline & & 6/6/47-Int. non-sec. & $\begin{array}{lll}16.6 & +26 & -53 \\
22 \mathrm{mg} . & 17 \mathrm{mg} . & 4.3 \mathrm{mg} .\end{array}$ & $\begin{array}{l}\text { Lactating. } \\
\text { No menses. }\end{array}$ & 19 \\
\hline 7. L.S. & Para ir $(3 / 8 / 47)$ & $\begin{array}{l}4 / 22 / 47 \text {-Int. hon-sec. } \\
\text { (Atrophy of stroma) }\end{array}$ & 46.6 & $\begin{array}{l}\text { Lactating. } \\
\text { Irregular spotting. }\end{array}$ & 7 \\
\hline 8. N.M. & $\begin{array}{l}\text { Para ii }(3 / 12 / 47) \\
\text { Iact. No mens. }\end{array}$ & 5/9/47-Int. non-sec. & $\begin{array}{lll}46.6 & -26 & -53 \\
36 \mathrm{mg} \cdot & 3.0 \mathrm{mg} \cdot & 3.0 \mathrm{mg} \cdot 3\end{array}$ & $.0 \mathrm{mg}$ & 8 \\
\hline & dur. prev. lact. & 5/23/47-Int. non-sec. & $\begin{array}{lll}16.6 & +26 & -53 \\
19.8 \mathrm{mg} \cdot & 9.1 \mathrm{mg} \cdot & 5.2 \mathrm{mg}\end{array}$ & $\begin{array}{l}\text { Lact. Exam shows } \\
\text { normal mens. flow. }\end{array}$ & 10 \\
\hline & & 6/27/47-Int. non-sec. & $+6.6-26$ & $\begin{array}{l}\text { L.M.P. } 5 / 23 / 47 \text {. } \\
\text { One day. Iactating. } \\
\text { No period in June. }\end{array}$ & $\boldsymbol{H}_{4}$ \\
\hline $\begin{array}{l}\text { 9. P.H. } \\
\text { 3I-Jr. C.F. }\end{array}$ & $\begin{array}{l}\text { Para iii }(3 / 6 / 47) \\
\text { Lact. No mens. } \\
\text { No.mens. or preg. } \\
\text { during prev.Iact. }\end{array}$ & 5/9/47-Int. non-sec. & $\begin{array}{l}\text { Specimen Toxic. } \\
\text { lice died. }\end{array}$ & $\begin{array}{l}\text { Pds. resumed 1-mo. } \\
\text { after lact. stopped } \\
\text { with prev. preg. }\end{array}$ & 9 \\
\hline
\end{tabular}




\begin{tabular}{|c|c|c|c|c|c|}
\hline PATIENT & HISTORY & BIOPSI & F.S.H.(MU) & COMMENT & T-PARTUM \\
\hline $\begin{array}{l}\text { 10. E.K. } \\
\text { 30-yr. C.F. }\end{array}$ & $\begin{array}{l}\text { Para v }(3 / 5 / 47) \\
\text { l4-mos. post-part. } \\
\text { no mens. Nursed } \\
\text { other babies } 6 \text { - } \\
\text { mos. Did not mens. } \\
\text { dur. lact. Resumed } \\
\text { Catamenia 3-mos af- } \\
\text { ter weaning. }\end{array}$ & $\begin{array}{l}\text { 5/20/47-Int. non-sec. } \\
\text { Atrophy of endometrium. } \\
\text { 6/30/47-Int. non-sec. }\end{array}$ & $\begin{array}{l}46.6+26-53 \\
35.3 \mathrm{mt} \cdot 10.3 \mathrm{mg} \cdot 3.0 \mathrm{mg} \cdot \\
46.6+26-53\end{array}$ & $\begin{array}{l}\text { Lactating. } \\
\text { Breasts congested. } \\
\text { No menses. } \\
\text { Not lactating. }\end{array}$ & 62 \\
\hline $\begin{array}{l}\text { II. M.D. } \\
\text { 21-yr. C.F. }\end{array}$ & $\begin{array}{l}\text { Para Ii }(4 / 4 / 47) \\
\text { Lact. No mens. } \\
\text { Did not nurse Ist. } \\
\text { babj. Catamenia } \\
\text { resumed @ } 2 \frac{1}{2}-\text { mos. } \\
\text { post-partum. }\end{array}$ & 5/16/47-Int. non-sec. & $\begin{array}{ll}16.6 & -26-53 \\
36 \mathrm{mg} . & 3.0 \mathrm{mg} \cdot 3.0 \mathrm{mg} . \\
& 3.1 \mathrm{mg} \cdot\end{array}$ & & 6 \\
\hline $\begin{array}{l}\text { 12. C.G. } \\
\text { 18-yr. C.F. }\end{array}$ & $\begin{array}{l}\text { Para i }(4 / 5 / 47) \\
\text { Lactating. } \\
\text { No mens. }\end{array}$ & $\begin{array}{l}\text { 5/23/47-Int. non-sec. } \\
\text { Thrombosis and } \\
\text { hyanilization. }\end{array}$ & $\begin{array}{lll}16.6 & -26 & -53 \\
10.1 \mathrm{mg} \cdot & 4.0 \mathrm{mg} . & 3.5 \mathrm{mg} .\end{array}$ & & 7 \\
\hline \multirow[t]{3}{*}{$\begin{array}{l}\text { 13. M.W. } \\
\text { 20-yr. C.F. }\end{array}$} & \multirow[t]{3}{*}{$\begin{array}{l}\text { Para i }(4 / 10 / 47) \\
\text { Lact. No mens. }\end{array}$} & 5/23/47-Late Int. Sec. & \multicolumn{2}{|c|}{$\begin{array}{lll}-26 & -53 & \text { (Should mens.within } \\
3.8 \mathrm{mg} & 3.6 \mathrm{mg} \text {. eight days. }\end{array}$} & 6 \\
\hline & & 6/20/47-Int. non-sec. & $\begin{array}{lll}46.6 & -26 & -53 \\
20 \mathrm{mg} \cdot & 12.2 \mathrm{mg} \cdot 4.1 \mathrm{mg} .\end{array}$ & $\begin{array}{l}\text { I.M.P. } 1 \frac{1}{2} \text {-days beg. } \\
5 / 24 / 47 . \text { Abscess of } \\
\text { breast mupt. spont. } \\
\text { Rx Stil besterol 5-mg. } \\
\text { daily } \times 5 . \\
\text { Not lactating. } \\
\text { Abscess healing. }\end{array}$ & 10 \\
\hline & & 6/27/47-Int. non-sec. & $\$ 6.6+26$ & $\begin{array}{l}\text { I.M.P. 3-days beg. } \\
6 / 24 / 47 . \text { Scanty. }\end{array}$ & 11 \\
\hline
\end{tabular}


The data in the preceding chart may be tabulated somewhat as follows:

Thirty-four F.S.H. determinations on 13 patients were done and 36-biopsies are reported. Two F.S.H. specimens were toxic and the mice assayed with these samples died before receiving the final injection.

The incidence of non-secretory endometrium was $97 \%$ (35 biopsies). The corresponding F.S.H. assays showed; 13 specimens positive for $6.6 \mathrm{Mu}$ and negative for $26 \mathrm{Mu}$, and 17 specimens positive for 26 Mu but negative for 53 Mu, giving a total of 30 F.S.H. specimens well within the normal limits of daily output for regularly menstruating, non-pregnant, nonlactating women. The incidence of normal F.S.H. in percent in this series is therefore $91 \%$. Two F.S.H. levels (6\%) were less than 6.6 wu per 24-hours and these were associcted with a nonsecretory endometrium. One F.S.H. level (3\%) was above 53 Mu but below $85 \mathrm{Mu}$ per 24-hours and this was associated with a nonsecretory enoiometrium. All three patients showing other than normal F.S.H. levels on one occasion had at least 3 or 4 other assays with the normal levels.

one biopsy of late interval secretory endometrium was obtained, the incidence being $3 \%$ (case 13). This was associated with a normaI F.S.H. Ievel (more than $6.6 \mathrm{Mu}$, less than $26 \mathrm{Mu}$ per 24-hours) and the patient had a scanty menstrual period which began about 36-hours after the biopsy was taken. 
Four patients $(30.7 \%)$ had catamenia resumed during this period of observation and of these, three were anovulatory and one ovulatory in nature (case 1,2,8, \& 13). Nine cases (69.3\%) were complete amenorrheas throughout the period of observation.

One patient with a breast abscess is interesting in that at six weeks post-partum a biopsy of secretory endometrium was obtained, and the patient had a scanty menstrual period beginning $1 \frac{}{2}$-days later. At 9 weeks the patient was seen again, at which time she had a breast abscess which had ruptured spontaneously. The endometrium on that day was non-secretory. The local breast lesion was treated and the patient given $5 \mathrm{mgm}$. of Stilibesterol dally for 5 days to dry up her breasts, and the baby weaned. At ten weeks post-partum (one month after the secretory biopsy) this patient showed a non-secretory endometrium and four days later had a scanty 3-day menstrual period. At 11 weeks post-partum the patient had a non-secretory endometrium. It is suggested that this patient's second menstrual cycle was anovulatory in nature and that the dose of stilbesterol given to control lactation from the breasts was also sufficient to inhibit ovulation in that cycle. All F.S.H. assays on the patient were normal.

One case of persistent amenorrhea at 14-months post-partum is presented (case 10). This patlent had two endometrial biopsies, both of which were non-secretory, the first being very atrophic. Both F.H.S. assays were within normal levels (more than 26 liu and less than 53 Mu per 24-hours). 


\section{V1 DISCUSSION}

In discussing this problem and the above data it is necessary to consider the reclassification of the amenorrheas in the light of our knowledge of F.S.H. which was presented by Albright. There may be primary ovarian failure with hy poestrinism as in the case of menopause patients. In this group F.S.H. is increased in the urine. There may be secondary ovarian fallure with hy poestrinism due to pituitary gonadatrophin failure. In this group F.S.H. is decreased in the urine, i.e., simmond's cachexia. A third group is now established in which there is hoptrinism with ovarian fallure associated with a normal F.S.H. output. There is a psychic factor present in this third group which cannot be overlooked, and it is conceivable that the hypothalamus is responsible in this group for the release of some precursor of estrin via the hy pothalamic-pituitary pathway which is non-estrogenic and which is inhibitory to F.S.H. In any case the level of F.S.H. In this class of hypothalamic amenorrheas is normal.

In animals it is established that coitus with subsequent nervous impulses is responsible via the hy pothalamic-pituitary tract for the release of luteinizing hormone (LH) necessary for ovulation but whether this is directly applicable to hunans is not known. We do know that F.S.H. causes ripening of ovarian follicies, that F.S.H. plus L.H. causes the follicle to produce estrin and to cause

Jovulation, that L.H. causes corpus luteum formation and that

L.H. plus luteotropin causes the corpus luteum to produce progesterone (17). 
It then becomes evident to suspect that amenorrhea associated with a normal F.S.H. output may be the result of dysfunction of the hypothalamic-pituitary nervous pathway governing the release of prolactin and L.H.

The predominence of a non-secretory endometrium in contrast to a secretory endometrium may indicate an absence of a functioning corpus luteum as previously speculated. The incidence of non-secretory and secretory endometrium in this series is consistent with that found by Topkins in a larger series.

The incidence of a normal F.S.H. in over $90 \%$ of specimens would indicate that this factor of the anterior pituitary is not suppressed during lactation and that lack of ovrlation and menstruation cannot be explained on the basis of lack of follicular maturation.

This finding is consistent with the unpublished data supplied by Dr. Anne Forbes concerning 9 assays of F.S.H. done on lactating women in $\mathrm{Dr}$. Fuller Albright's laboratory. All 9 of these assays were within the normal levels as stated herein, (personal communication). 


\section{CONCLUSIONS}

From this study the only conclusions justified are: 1. that the anterior-pituitary gland output of F.S.H. during lactation is normal in $90 \%$ of cases; 2. that there is no relation between this level of F.S.H. and the incidence of menstruation or ovulation during lactation; 3 . that the amenorrhea of lactation is not due to failure of the follicle to receive its growth stimulus.

It may be justifiable to suppose that the anenorrhea of lactation may be due to a lack of L.H. or luteotropin and that a hy pothalamic-pituitary nervous mechanism may be responsible for this.

\section{SUMMARY}

The problem of the amenorrhea associated with lactation is presented, the literature reviewed and the incidence of catamenia discussed. Thirteen cases oflactation amenorrhea, complete and incomplete, are studied and reports of 36 endometrial biopsies and 34 F.S.H. assays are given. The incidence of non-secretory endometrium is found to be $97 \%$, of secretory endometrium 3\%. The incidence of normal daily levels of F.S.H. is $91 \%$. Sixty-nine percent of patients were complete amenorrheas and $31 \%$ had catamenia re-established during the period of observation. The significance of the observations are considered and it is concluded that the amenorrhea of lactation is not due to suppression of the anterior pltuitary follicle stimulating factor. 


\section{BIBLIOGRAPHY}

1. Fortune, R.F.: Arapesh Maternity Nature (London). (N.W. New Guinea) 152:164, August 7, 1943.

2. Novak, E.: Endocrines in Pregnancy, Lactation and Puer perim. J.Cl. Endo. 3:214. 1943.

Hoskins, R.G.; Endocrinology lst Edition Cl Il 1941. Norton \& Co.

3. Topkins, Paul: The Histological Appearance of the Endometrium during Lactation Amenorrhea and Its Relationship to Ovarian Function. Am.J. Ob.-Gyn. 45:48 1943.

4. Ross, R.A.: Study of Endometrium as an Indicator. So. Med. Jr. 32:52 - 1939 .

5. Jungck, Maddock, Heller: Gonadatropic Hormone; UltraFiltration and Alcohol Precipitation Methods. J. Cl. Endo. 7:1 1947 .

6. Cherry: Action of Mammary Gland on Ovary. J. Lab. \& Cl. Med. 22:711-136-37.

7. Griffith-McBride: Clinical Uses of Endometrial Biopsy. J. Mich. Med. So. 38:1064 - 137.

8. Kurzrak, Lass, Smelser: Studies Relating to the Time of Human Ovulation during Lactation. Proc. Soc. Exp. Biol. \&. Med. $36: 356-137$.

9. Lass, Smelser, Kurzrek: 111 Relating to Time of Human Ovulation During Lactation. Endo. 23:39 - 1938.

10. Wilson, Randall, Osterbery: Studies on Pregnandiol. Amer. J. Ob.-Gn. 37:59 - 1939 . 
11. Robinson: Falling Lactation. Lancet 1:66, (June 16) 1943.

12. Bates, Lahr, Riddle: The Grossaction of Prolactin and F.S.H. Hormones on the Mature Ovary and Sex Characteristics of Fowl. Am. J. Phy siol. 111:361 -135.

13. Riddle \& Bates: Concerning Anterior Pituitary Hormones. Endo. 17:689. 133 .

14. Turner-Mixner: Role of Estrogens in Stimulation of Mammary Lobule-AIveolar growth by Progesterone and Manmogenic Growth Factor of Pit. Endo. 30:596 - 142.

15. Turner-Meites: Does Pregnancy Suppress Lactogenic Hormones of Pitultary 2 Endo. 29:165 - 141.

16. Collip, Selye, Thomson: Nervous ana Hormonal Factors in Lactation. Endo. 18:237 - 134 .

17. Albright, Smith, Dodge: Quantatative Method for the Determination of Normal or Decreased Amounts of F.S.H. J. Cl. Endo. 3:529-143.

18. Albright, Smith, Dodge: Modification in Methods of Precipitation and Assay of Increased Amounts of Pit. Gonadatropic Substance in Urine. J. Lab. \& Cl. Med. Vol. 28, Part 2, p. 1261. 1942-43.

19. Heller \& Heller: Gonadatropic Hormones. Clinfcal Applications of Bxtraction Method for Assay Purposes. Endo. 24:319 - 1939.

20. Levin-Tyndale: The quantatative Assay of "F.S." Substances. Endo. 21:619-137. 